\title{
An Assessment of Human Capital Development in Nigeria through the Lens of Education
}

\author{
Martins lyoboyi ${ }^{1, *}$, Olarinde Muftau ${ }^{2}$ \\ ${ }^{1}$ Department of Economics \& Development Studies, Federal University, \\ Dutsin-ma, Katsina State, Nigeria \\ *Tel: +2348037954183 \\ ${ }^{2}$ Department of Economics, Usmanu Dan Fodiyo University, Sokoto, Nigeria \\ *E-mail address: miyoboyi@gmail.com , miyoboyi@fudutsinma.edu.ng
}

\begin{abstract}
The paper assesses human capital development in Nigeria through the lens of education. The study used education as proxy to capture human capital, while utilizing secondary sources of data. There is evidence that human capital development in Nigeria is inadequate and unable to galvanise the economy towards long-term stable growth. Emphasis should be placed on deliberately developing the country's vast human resources, with particular reference to the country's educational spectrum, if the goal of poverty alleviation, employment generation and wealth creation, all encapsulated in various policy documents over the years, are to be achieved.
\end{abstract}

Keywords: Education; Growth; Health; Human Capital; Nigeria

JEL classification: C01, C22, H51, I18.

\section{INTRODUCTION}

The need to adequately develop a nation's human capital on a sustainable basis cannot be overemphasized in a nation's economic and social progress. Education is a key index of development. It is generally agreed upon by experts as a key driver of human capital development, the importance of which has been articulated in various documents including the Universal Declaration of Human Rights (1948), the International Covenant on Economic, Social and Cultural Rights (1966) and the African Charter on Human and Peoples' Rights (1981).

Investment in human capital through the provision and sustenance of quality education is crucial to the development of society. Modern growth theories generally conclude that the accumulation of human capital is an important source of economic growth. Many studies have shown a consistently positive relationship between the education of the workforce and labour productivity (Trostel et al, 2002). This is because better education tends to be associated with better employment opportunities, greater earnings, and greater capacity for production. Education is thus considered an investment which equips individuals with knowledge and skills that improve their chances of future and higher earnings. 
The imperatives of education as a medium of human capital development go beyond the acquisition of skills which prepare the individual for work to one which instills the skills necessary for formulating, synthesizing and analyzing a matrix of issues. Education promotes positive civic behaviors, while cementing social cohesion which consequently consolidates the social capital of a nation. Because of the increasing integration of the world economy, driven inevitably by technology, education has fast become critical in providing a society's workforce to meet the stiff competition of a global community.

Because a society's human capital is inextricably linked to its educational system, it is not surprising that the more and better education often reflects in the degree of development. Consequently, the Nigerian educational system cannot be said to have produced the right cord for development. With dilapidated structures, poor remuneration system, coupled with very poor learning environments, incessant industrial strikes, incongruence between the academic curricula and industrial needs, the country has had to pay a huge penalty due to the educational crisis and consequently to low human capacity building.

Nigeria is generally reckoned as one with vast human and natural resources. Yet, it is paradoxical that she is still bedeviled by a plethora of developmental challenges, so much so that 50 years after her political independence, she is still in the development wilderness. The study is therefore aimed at assessing human capital development in Nigeria through the lens of the educational sector. Following the introduction, the rest of the paper has the following structure. Literature is covered in Section 2. A critical assessment of human capital development in Nigeria is undertaken in Section 3. The paper is concluded in Section 4.

\section{LITERATURE}

It is agreed among development theorists that economic growth and development are significantly impacted by the quality of human resources. This is because labour, being a factor of production, its quality and quantity go a long way in determining the level of production. Entrepreneurship does well in an environment of critical thinking and ideas, which can take advantage of changing environment through innovation, with education providing the means to that end (Roux, 1994).

Harbison (1973) posits that what constitute the ultimate basis for the wealth of nations are human resources, in that the development of a nation is carried forward, not by capital and natural resources which are passive factors of production but human beings, who being active agents in the production process, accumulate capital, exploit natural resources and consequently build social, economic and political organizations. Human capital development ensures that a nation's labour force is improved on a continuous basis to meet the challenges of the changing environment, with education being a critical element in the process (Yesufu, 2000). Many studies have found positive correlation between investment in education and economic growth, and it is for this reason that many policy frameworks encapsulate the critical role of education as a worthy trajectory. From the foregoing, it follows that human capital development is a strategy of growth and development which must be embarked upon in order to achieve sustainable growth within a given time period (Olaniyan \& Okemakinde, 2008; Griffin \& McKinley, 1992).

Developing a nation's human capital involves systematic manpower planning in consonance with developmental needs. It is for this reason that a direct relationship between the level of human capital development and productive capacity is consistently found in 
empirical studies. This is particularly noteworthy in that emphasis on comparative advantage is shifting from possession of natural endowments to knowledge engineering.

The educational system is one way of analyzing the state of a country's human capital development. This is underscored on the fact that as human capital is encapsulated in the individual's ability and efficiency to engage in the transformation of raw materials into greater values, the educational system provides the leverage on which these skills can be transmitted. It is because of this that studies on human capital development by experts usually deals with such metrics as test scores (Hanshek \& Woessman, 2009), years of schooling (Cohen \& Soto, 2007), literary rates (Azariades \& Drazen, 1990), and rates of school enrolment (Barro, 1991).

Investment in functional education is one of the bedrocks of modern growth and development. It is a ready source of human empowerment which has the capacity of alleviating poverty through skill acquisition and promotion, self-employment and greater opportunities in a fast changing global environment. Emphasis is increasingly shifting from traditional approaches to poverty alleviation and capacity building to one where education (as seen from the quantum of government investment in the sector) is considered a long-run panacea to low living standards and poverty. It is the opinion of scholars that no meaningful change in the form of reforms or economic adjustments can occur in the absence of human imperatives (Adedeji et al., 1990). Unfortunately, Africa and many developing countries have failed to take advantage which increased human development though adequate and functional education can provide, and Nigeria is by no means an exception. With severe crisis in her educational sector, it is not surprising why she has tended to be consistently ranked low in the various development indicators over the years.

\section{A SURVEY OF HUMAN CAPITAL DEVELOPMENT IN NIGERIA}

\section{1. Literacy rate}

Adult literacy in Nigeria was 50.1 in 1989. It however rose to 55 in 1993 and 1994. According to a 2003 estimate, Nigeria's literacy rate was 68 percent on average. Males had a higher rate (75.7 percent) compared to females (60.6 percent). At the secondary school level, the rate of attendance for male was 32 percent while for females it was 27 percent (Library of Congress, 2006). Literacy levels in other countries for the same period were, $77 \%$ in Indonesia, $60 \%$ in China and even among African countries, $67 \%$ in Zimbabwe. In 2006, the literacy rate was $60.4 \%$ (Eneh, 2011).

\section{2. Academic standards}

The decadence in various training and academic institutions has become pervasive. Decadence is reflected in such dimensions as academic dishonesty and cultism, both of which have negatively impacted quality. Oluyeba and Daramola (1992) consider academic dishonesty to involve examination leakages, cheating, swapping of examination scripts, smuggling of answer scripts in the examination halls, collusion, result and certificate forgery, impersonation, and verbal and physical assault on examination administrators. This is in addition to fabrication and plagiarism. Academic dishonesty now cuts across the entire educational spectrum and it is not a recent phenomenon (Ikupa, 1997). 
According to the West African Examinations Council (2004), there were incidents of examination malpractices from 1994 through 2003. Though incidents of academic dishonesty in Nigeria's higher education is not well documented, incidents of examination malpractices in states and geo-political zones in Nigeria show that in spite of efforts put in place by the examination ethics project between 2003 and 2004, the oddity increased by $40 \%$ (Examination Ethics Project 2004, as cited in Amalu, 2005).

The intense competition to access the educational system has brought with it an inevitable quest to have basic admission requirements at all costs. The result has been examination practice, which has assumed a monstrous proportion. Alarming cases of cancellation of examinations and rustication of students involved in examination malpractices are rife in all strata of the Nigerian educational spectrum.

The problem of cultism especially at higher levels of education cannot be insulated from the operations of the wider society. With a massively derailed value system, buttressed and reinforced by brutal drive for foreign values, coupled with emphasis on paper qualification by the larger Nigerian society, overcrowding, admission irregularities orchestrated by skewed reasoning and dilapidated faculties at all levels of education, it is not perhaps strange that alienation of the majority of the young and a feeling of frustration and anger have provided the bulwark to use cult activities as a form of safety net.

Discipline has thus nosedived in many institutions, while learning quality has been severely compromised.

Table 1 shows the performance of students in two public examinations in Nigeria between 2003 and 2008 .

Table 1. Nigeria's Public Examination Results.

\begin{tabular}{|c|c|c|c|c|c|c|c|c|c|c|c|c|}
\hline & \multicolumn{2}{|c|}{2003} & \multicolumn{2}{|c|}{2004} & \multicolumn{2}{|c|}{2005} & \multicolumn{2}{|c|}{2006} & \multicolumn{2}{|c|}{2007} & \multicolumn{2}{|c|}{2008} \\
\hline & ${ }^{*}$ & $\begin{array}{l}\text { *0 } \\
\text { 号 } \\
\text { Z }\end{array}$ & 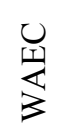 & $\begin{array}{l}0 \\
\text { Oy } \\
\text { Z }\end{array}$ &  & $\begin{array}{l}0 \\
\text { Oy } \\
\text { Z }\end{array}$ & 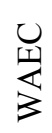 & $\begin{array}{l}0 \\
\text { Oy } \\
Z\end{array}$ & 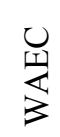 & $\begin{array}{l}0 \\
\text { O } \\
\mathbf{Z}\end{array}$ & 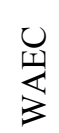 & $\begin{array}{l}0 \\
\text { D } \\
Z\end{array}$ \\
\hline $\begin{array}{l}\text { Total number } \\
\text { of } \\
\text { candidates who } \\
\text { sat for } \\
\text { the exam } \\
\text { ination }\end{array}$ & 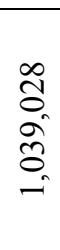 &  & 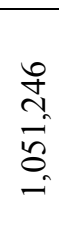 & $\begin{array}{l}\frac{n}{n} \\
\hat{2} \\
\hat{\infty}\end{array}$ & $\begin{array}{l}\hat{0} \\
\hat{a} \\
\overrightarrow{0}\end{array}$ & 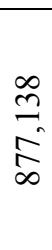 & 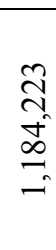 & $\begin{array}{l}\infty \\
\stackrel{0}{\kappa} \\
\tilde{n} \\
\alpha\end{array}$ & 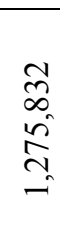 & $\begin{array}{l}0 \\
\text { ñ } \\
\text { in } \\
0\end{array}$ & $\begin{array}{l}\vec{I} \\
\overrightarrow{0} \\
\stackrel{-}{n}\end{array}$ & $\begin{array}{l}0 \\
0 \\
\infty \\
= \\
=\end{array}$ \\
\hline $\begin{array}{l}\text { Candidates } \\
\text { with minimum } \\
\text { of five (5) } \\
\text { credits } \\
\text { (including } \\
\text { English lang. \& } \\
\text { Mathematics) }\end{array}$ &  & $\underset{\stackrel{N}{+}}{\stackrel{N}{\sim}}$ & $\begin{array}{l}\infty \\
\tilde{\sigma} \\
\hat{\Omega}\end{array}$ & $\begin{array}{l}\stackrel{0}{\infty} \\
\infty \\
\stackrel{f}{ \pm}\end{array}$ & $\begin{array}{l}\bar{\sigma} \\
\hat{\sigma} \\
\hat{\sigma}\end{array}$ & $\begin{array}{l}\vec{F} \\
\dot{\infty}\end{array}$ & $\begin{array}{l}\vec{\partial} \\
\vec{\sigma} \\
\stackrel{0}{ }\end{array}$ & $\begin{array}{l}a \\
0 \\
\infty \\
n \\
n\end{array}$ & $\underset{\infty}{\stackrel{m}{\infty}}$ & $\begin{array}{l}\bar{D} \\
\text { oे } \\
\text { Oे }\end{array}$ & $\begin{array}{l}\text { 于 } \\
\text { I }\end{array}$ & $\begin{array}{l}\text { o } \\
\text { Lे } \\
\text { ơd }\end{array}$ \\
\hline
\end{tabular}




\begin{tabular}{|c|c|c|c|c|c|c|c|c|c|c|c|c|}
\hline $\begin{array}{l}\text { Percentage of } \\
\text { candidates witl } \\
\text { minimum } \\
\text { of five (5) } \\
\text { credits } \\
\text { (including } \\
\text { English } \\
\text { language \& }\end{array}$ & $\begin{array}{l}\stackrel{2}{2} \\
\stackrel{2}{2}\end{array}$ & 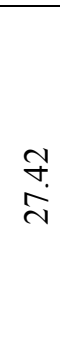 & $\begin{array}{l}\text { N } \\
\infty \\
\infty\end{array}$ & fo & $\begin{array}{l}\infty \\
\dot{0} \\
\infty\end{array}$ & $\bar{n}$ & $\tilde{n}$ & $\stackrel{\sim}{\stackrel{\sim}{N}}$ & $\underset{\sigma}{\sigma}$ & $\begin{array}{l}\bar{n} \\
0 \\
0\end{array}$ & ते & $\begin{array}{l}\text { oे } \\
\text { in }\end{array}$ \\
\hline
\end{tabular}

${ }^{*}$ Results for May/June

${ }^{* *}$ Results for June/July

Source: West African Examinations Council; National Examinations Council.

Low level of teacher effort, engendered by official apathy to the plight of teachers and the reckless state of existing infrastructure are some of the factors responsible for the decadence of educational standards in Nigeria. Park and Hannum (2002) showed that teacher effort is crucial to the process of learning. Consequently, when teacher effort is low through such actions and behaviour as teacher absence, negligence and indifference, the effects are destructive to effective learning.

The effects of teacher absence for example are replete in the literature. A study by Das et al (2007) found that in Zambian primary schools, an increase in absence duration of one day per month reduced test scores by about $4 \%$ to $8 \%$ of the average yearly gains in Mathematics and English. In a study conducted in India on non-formal schools by Duflo et al. (2008), test score gains of 0.2 standard deviations were recorded, a figure that corresponded to a reduction of teacher absence by fifty percent.

Acquiring skills and competencies is a cumulative process. Group studies in developed countries show evidence that a strong correlation exists between cognitive skills while young and competencies in adult life (Case \& Paxson 2008). When pupils in the primary schools are not given the right type of learning, the effects are usually long-lasting. Productivity in later years is negatively impacted when there are learning deficiencies at an early age, as confirmed by studies (Case et al., 2002). This accounts for the prevailing deficiencies experienced in post-primary and post-secondary institutions in Nigeria.

In a 2008 ranking of universities, 8 of the top 10 were in the Unites States of America and 37 of the top 50 in the same country. No Nigerian university ranked among the first 6000. The ranking of the top 100 African universities in 2011 places the best university in Nigeria in the $30^{\text {th }}$ position.

According to the World Bank (2003), Nigeria, Africa's largest country with 20 percent of the continent's population, had only 15 scientists and engineers engaged in research and development per million persons, in comparison with other countries like Brazil (168), China (459), India (158) and the United States $(4,103)$. She did not compare very well in terms of scientific publication, where in 1995, for instance, the country had only 711 scientific publications, compared to South Africa with 3,413, India with 14,883 and Brazil with 5,440.

The problem of quality of higher education is not unrelated to disconnect at lower levels. In 2008 in Kwara State, 20,000 teachers underwent an assessment test that was based on a Primary 4 literacy and numeracy curriculum. Out of these, only 75 could meet the minimum competency threshold established at $80 \%$. Ironically, majority of those who scored zero in the test hold university degrees (Saraki, 2009). 


\section{3. Funding}

Although studies show that in developing countries, teacher remuneration accounts for nearly three-quarters of recurrent expenditure (Bruns et al., 2003), this does not seem to be applicable to Nigeria. Between 1977 and 2005, the percentage allocation by the Nigerian government to the education sector ranges from 2.20 percent to 8.94 percent of the total government expenditure. Meeting the 25 percent budgetary allocation recommended by the UNESCO is a far cry. Compared to other countries in Africa, the budgetary allocation to education in Nigeria is dismally low. For example, budgetary allocation to education in Singapore is $23.60 \%$, South Africa $28.80 \%$, Cuba $15.10 \%$ Algeria $21.10 \%$ and Ghana $30.00 \%$ (ASUU, 2007).

Budgetary allocation to recurrent education expenditure has been low. Budgetary allocations on recurrent expenditure on education in Nigeria are shown in Table 2.

Table 2. Budgetary Allocation (Recurrent Expenditure) to Education in Nigeria.

\begin{tabular}{cccc}
\hline Year & $\begin{array}{c}\text { Total Recurrent } \\
\text { Expenditure budget } \\
\text { (N'million) }\end{array}$ & $\begin{array}{c}\text { Education } \\
\text { Expenditure budget } \\
\text { (N'million) }\end{array}$ & $\begin{array}{c}\text { Education } \\
\text { Expenditure as o/o of } \\
\text { Total Recurrent } \\
\text { Expenditure }\end{array}$ \\
\hline 1985 & 11237.8 & 669.5 & 5.96 \\
1990 & 27208.4 & 1962.6 & 7.21 \\
1995 & 108936.6 & 9421.3 & 8.65 \\
2000 & 353126.5 & 44225.5 & 12.52 \\
2005 & 1093054.0 & 92594.7 & 8.47 \\
2006 & 1343045.2 & 129421.9 & 9.64 \\
2007 & 1056563.9 & 137478.26 & 13.01 \\
\hline
\end{tabular}

Source: Central Bank of Nigeria; Authors' computations.

Apart from budgetary allocation to recurrent education expenditure which has been low over the years, actual government recurrent expenditure on education has been generally unenviable, as presented in Table 3.

Table 3. Government recurrent expenditure on education (in 'million).

\begin{tabular}{cccc}
\hline Year & $\begin{array}{c}\text { Total Recurrent } \\
\text { Expenditure }\end{array}$ & $\begin{array}{c}\text { Education } \\
\text { expenditure }\end{array}$ & \% of total \\
\hline 1965 & 156.84 & 10.61 & 6.76 \\
1970 & 716.10 & 24.44 & 3.41 \\
1975 & $2,734.90$ & 126.54 & 4.63
\end{tabular}




\begin{tabular}{cccc}
1980 & $4,805.20$ & 155.81 & 3.24 \\
1985 & $7,576.4$ & 258.60 & 3.41 \\
1990 & $36,219.60$ & $2,402.80$ & 6.63 \\
1995 & $127,629.80$ & $9,746.40$ & 7.64 \\
2000 & $461,600.0$ & $57,956.64$ & 12.56 \\
2005 & $1,321,229.99$ & $82,797.11$ & 6.27 \\
2010 & $3,109,378.51$ & $170,770.56$ & 5.49 \\
2011 & $3,314,513.33$ & $335,837.89$ & 10.13 \\
\hline
\end{tabular}

Source: Central Bank of Nigeria. ${ }^{*}$ Computed by authors.

Government capital expenditure component on education has been generally uneven over the years. Budgetary allocation (capital expenditure) to education in Nigeria is shown in Table 43.

Table 4. Budgetary Allocation (Capital Expenditure) To Education in Nigeria.

\begin{tabular}{cccc}
\hline Year & $\begin{array}{c}\text { Total Capital } \\
\text { Expenditure budget } \\
\text { (N' million) }\end{array}$ & $\begin{array}{c}\text { Education } \\
\text { Expenditure } \\
\text { budget (N'million) }\end{array}$ & $\begin{array}{c}\text { Education } \\
\text { Expenditure (\% of } \\
\text { Total Capital } \\
\text { Expenditure) }\end{array}$ \\
\hline 1985 & 6516.4 & 180.7 & 2.77 \\
1990 & 9055.6 & 331.7 & 3.66 \\
1995 & 44559.0 & 3307.4 & 7.42 \\
2000 & 311608.8 & 23342.6 & 7.49 \\
2005 & 706884.2 & 27440.8 & 3.88 \\
2006 & 556964.8 & 35791.8 & 6.43 \\
2007 & 883830.9 & 48293.51 & 5.46 \\
\hline
\end{tabular}

Source: Central Bank of Nigeria; Authors' computations.

Actual government capital expenditure on social community services (i.e. education, health and other social services) is far from being encouraging over the years, as shown in Table 5 . 
Table 5. Government Capital expenditure on social community services (1965-2011).

\begin{tabular}{ccc}
\hline Year & Capital expenditure & \% of total \\
\hline 1965 & 9.4 & 11.8 \\
1970 & 1.4 & 0.7 \\
1975 & 927.4 & 28.9 \\
1980 & $2,456.7$ & 24.2 \\
1985 & $1,154.0$ & 21.1 \\
1990 & $2,096.0$ & 8.7 \\
1995 & $9,215.6$ & 7.6 \\
2000 & $27,965.2$ & 11.7 \\
2005 & $71,361.2$ & 13.7 \\
2006 & $78,681.3$ & 14.2 \\
2007 & $150,895.2$ & 17.3 \\
2008 & $152,174.6$ & 15.8 \\
2009 & $120,696.9$ & 10.4 \\
2010 & $147,409.5$ & 11.9 \\
2011 & $91,926.2$ & 10.0 \\
\hline
\end{tabular}

Source: Central Bank of Nigeria

Government's budgetary allocation to capital expenditure on education has been unfortunately low since 1985 , ranging from $2 \%$ to $9 \%$. It has been pitiably uneven. In 2000 , recurrent spending per student in Nigeria was increased to $\$ 900$. This was in sharp contrast in the same period to the United States $(\$ 9,629)$, United Kingdom $(\$ 8,502)$, Japan $(\$ 4,830)$, Germany $(\$ 11,000)$, India $(\$ 400)$, China $(\$ 2,728)$, Russia $(\$ 1,024)$, Brazil $(\$ 3,986)$, Malaysia $(\$ 11,790)$ (Saraki, 2009).

The sectoral contribution of education in terms of value-added to gross domestic product has been generally low. Table 4 shows the percentage points between 1985 and 2009 . It has been particularly lower since 2000 than in the 1980s and 1990s.

Table 6. Sectoral Contribution to GDP (Percentage points), 1985-2009.

\begin{tabular}{cccc}
\hline Year & $\begin{array}{c}\text { Real GDP* } \\
\left(\text { Nm}^{*}\right.\end{array}$ & $\begin{array}{c}\text { Education } \\
\left(N^{\prime} \mathrm{m}\right)\end{array}$ & $\begin{array}{c}\text { Percentage } \\
\text { Contribution }\end{array}$ \\
\hline 1985 & $201,036.3$ & 508.1 & 0.25 \\
1990 & $267,550.0$ & 562.4 & 0.21 \\
1995 & $281,407.4$ & 609.8 & 0.22 \\
2000 & $329,178.7$ & 670.9 & 0.20 \\
2005 & $561,931.4$ & 964.5 & 0.17 \\
2006 & $595,821.6$ & $1,068.4$ & 0.18 \\
2007 & $634,251.1$ & $1,183.6$ & 0.19 \\
2008 & $672,202.6$ & $1,311.0$ & 0.20 \\
2009 & $716,949.7$ & $1,442.2$ & 0.20 \\
\hline
\end{tabular}

*Gross Domestic Product at 1990 Constant Basic Prices

Source: National Bureau of Statistics; Authors' computations. 


\section{4. Access}

Access to Nigerian educational institutions at all tiers is far from being adequate. The nature of access to university education in Nigeria for example is illustrated in Table 7.

Table 7. Application and Admission via Universities Matriculation Examination, 2000/2001- 2004/2005.

\begin{tabular}{cccc|ccc|c|c}
\hline \multirow{2}{*}{ Session } & \multicolumn{3}{c|}{ Application } & \multicolumn{3}{c|}{ Admitted } & \multirow{2}{*}{ Shortfall } & $\begin{array}{c}\text { \% of } \\
\text { access }\end{array}$ \\
\cline { 2 - 7 } & Male & Female & Total & Male & Female & Total & & \\
\hline $2003 / 2004$ & 603,176 & 443,764 & $1,046,940$ & 59,743 & 48,117 & 107,860 & 939,080 & 10.3 \\
$2004 / 2005$ & 484,217 & 353,834 & 838,051 & 69,717 & 52,779 & 122,496 & 715,555 & 14.6 \\
$2005 / 2006$ & 527,180 & 390,780 & 917,960 & 45,256 & 31,728 & 76,984 & 840,976 & 8.4 \\
$2006 / 2007$ & 521,170 & 391,180 & 912,350 & 70,961 & 47,095 & 118,056 & 794,294 & 12.9 \\
$2007 / 2008$ & 578,715 & 455,368 & $1,034,083$ & 28,475 & 19,019 & 47,494 & 986,589 & 4.6 \\
\hline
\end{tabular}

Source: Joint Admissions and Matriculation Board; Authors' computations.

Accessibility to Nigerian university education depends, among other factors, on state of origin, educationally less developed state status, merit and "catchment". The number of institutions available is also crucial, as the higher the number of institutions, the higher is the absorptive capacity of universities for applicants and vice versa. As at 2007, Nigeria had 93 universities. This figure compares unfavourably with such countries as Japan with about 1000, India with about 8400 universities and the United states with about 5300 universities. The number of universities as at 2011 was 118, made up of 36 federal, 37 state and 45 private universities (National Universities Commission, 2011).

Availability of infrastructure and facilities are a determinant of the universities' absorptive capacity. Increase in the number of institutions at all levels is not reflective of increase in the general population. It is common sense to tie the increases in educational institutions and facilities to potential increases in the general population. Available institutions cannot therefore adequately support the pool of applicants at all tiers of education in Nigeria.

\section{5. Gender disparity}

Gender inequity and discrimination are prevalent in Nigeria. Many productive women are rendered handicapped by cultural and traditional constraints. The attention given to girlchild education is abysmal. Politically, achieving the $30 \%$ inclusion of women in the political space is a monumental mirage. Afonja (1988) maintains that there is a feedback relationship between the macro and the micro levels of the operation of gender stratification in Nigeria, with the structures, processes and actors precipitating and reinforcing the phenomenon.

In terms of the ratio of girls to boys at all levels of education, the picture is discouraging. The proportion of girls enrolled is still lower than that of boys across all levels of education, although for university admissions, there have been signs of improvement. Specifically, the ratio of girls to boys in primary education shows long-term progress, 
although there are occasional deviations (Table 6). In 1990, the ratio of girls per 100 boys was 76 while in 2008 the number of girls per 100 boys was 85.4, a sign of positive trend.

The situation in secondary education is relatively worse. For instance, while in 2000 , the ratio was 81, it fell to 79.9 in 2008, although between 2007 and 2008, there was a slight increase from 79.4. In general terms, there has been slow progress.

The ratio of girls to boys in tertiary education is the worst. While in 1990 , the number of girls per 100 boys was 46, the figure rose to 66 in 2000 through 2004 but declined in 2006 and fell further in 2008 as shown in Table 8.

Table 8. Gender Disparity in Primary, Secondary and Tertiary Education in Nigeria.

\begin{tabular}{|c|c|c|c|c|c|c|}
\hline Indicator & 1990 & 2000 & 2002 & 2004 & 2006 & 2008 \\
\hline $\begin{array}{c}\text { Ratio of girls to boys in } \\
\text { primary education (girls per } \\
\text { 100 boys) }\end{array}$ & 76 & 78 & 79 & 81 & 83 & 85.4 \\
\hline $\begin{array}{c}\text { Ratio of girls to boys in } \\
\text { secondary education (girls } \\
\text { per 100 boys) }\end{array}$ & 75 & 81 & 80 & 77.4 & 79.4 & 79.9 \\
\hline $\begin{array}{c}\text { Ratio of girls to boys in } \\
\text { tertiary education (girls per } \\
\text { 100 boys) }\end{array}$ & 46 & 66 & 87 & 75.5 & 69 & 66.8 \\
\hline $\begin{array}{c}\text { Proportion of seats held } \\
\text { by women in the National } \\
\text { Parliament (\%) }\end{array}$ & 1.0 & 3.1 & 3.1 & 3.1 & 3.1 & 7.5 \\
\hline
\end{tabular}

Source: Federal Government of Nigeria

\section{6. Curriculum}

The right curriculum is capable of allowing technology to diffuse through education. Education and technology diffusion is abnormally low in Nigeria. Technology, reflected in Research and Development is the most powerful impetus of industrial performance (UNIDO, 2003). Attracting foreign direct investment and talents, building Information and Communications Technology (ICT) infrastructure and investing massively in human capital are imperative to a country's economic rejuvenation (Gorki, 2001). Access to ICT and socioeconomic development are positively correlated. Huyer and Sikoski (2003) maintained that the stimulation of economic development and a country's ability to leapfrog economic growth stages depend significantly on the people's capacity to get education, starting from the primary through the university. This is in addition to relating to the aggregate development of cultural patterns, information diffusion among the citizenry as well as the level and content of functional literary. Consequently, information poor societies like Nigeria lack well-developed ICT infrastructure and lack the capacity to manufacture and generate wealth for its people (Jensen, 2001).

Using ICT as a tool of innovation will go a long way in improving productivity. Majority of the people in Nigeria are predominantly rural, traditional and are skeptical. Developing a curriculum reflective of ICT will assist learners/students and the general populace to embrace experimentation, adoption and innovation using modern facilities (Kombol, 2006).

The failure in Nigeria to teach science, technology and other allied studies in an effective manner can be said to be a direct result of the inadequacy of curriculum as used in 
schools, especially as it does not reflect the peculiarity of the local environment. At higher levels, education must reflect the requirements of a globalized world and address questions of information and telecommunications technology and how the local environment can respond to rapidly changing economic, political and social horizons. Current attention to high level skills through adequate development of post-graduate studies in order to produce new knowledge is critically lacking in Nigeria. Moja (2000) asserts that with outdated methods of training and teaching approaches, little or no emphasis is placed on the dynamic environment in which teaching takes place, especially the requirements of a global environment in which technology is imperative.

\section{CONCLUSIONS}

The paper aimed at assessing human capital development in Nigeria. Human capital development is a prerequisite for a nation wanting to exit the pigeon hole of depression, increase its output and promote general welfare. Developing it through a matrix of policy options is fundamental. Education is pivotal to the development of human capital, with the effect that proxy measures such as rates of school enrolment and literacy rates when improved can have positive impact on generating the productivity needed for an economy to bounce back from production lethargy. It is only when human capital is utilized in the labour market that increased productivity can be realized, so that the workings and conditions prevalent in the labour market are crucial to policy measures.

The need to commit more funds to education at all levels is germane. Developing Nigeria's human resources is not negotiable if the goal of economic rejuvenation is to be attained. This is underpinned on the fact that in a digital age, knowledge is the most important source of growth and development, and no nation can afford to pay lip service to the development of its most critical infrastructure.

Emphasis on science and technology is imperative. This requires a holistic linking of technology to industry through an overhaul of curricula and investment prioritization. The output from various tiers of education should reflect industry needs. Nigeria's institutional framework lacks a bottom-up approach where users of educational facilities, as stakeholders in national development and transformation define educational policies.

Gender disparity and inequality to access to education exacerbate existing economic morass. The disturbing status of educationally less developed states has shown marginal if any change for many years. Use of adult literary is imperative and where inaccessibility is acute, programmes aimed at targeting specific areas through spatial resource allocation should be implemented. Distance learning should be intensified to increase rural access and bridge rural-urban educational chasm.

Quality of teachers and output from educational institutions are basic to skill development and attendant productivity. Teacher training must be on a continuous basis. Institutions should be empowered to execute capacity building and strengthen their manpower. Curriculum that reflects the goals of development and the changing global economic, political and social landscapes needs to be developed.

Nigeria's policy on education needs to be aligned with economic policy. Priority should be on economic needs, which are to be reflected on educational curricula. Budgetary allocation should be tailored on the short, medium and long term horizon with timely release of funds, coupled with the appropriate executive machinery for implementation. 


\section{References}

[1] Academic Staff Union of Universities (ASUU), 2007. The State of the Nation, April 9. Retrieved on the web 22/12/07.

[2] Adedeji A, Rasheed S, Morrison M, 1998. The Human Dimension Africa's Persist Economic Crisis. United Nations Economic Commission for Africa. Hans Zell Publisher, pp. 377-391.

[3] Afonja S, 1988. Critical Issues in Women's Studies in Nigeria - a Sociological Perspective. A paper presented at the workshop for the Canadian- Nigerian Linkage in Women Studies, held at Obafemi Awolowo University, January.

[4] Amalu C, 2005. Examination fraud increased by 40\% in 2003-2004. Nigerian Vanguard, pp. 11. October 3.

[5] Azariadis C, Drazen A, 1990. Threshold Externalities in Economic Development. Quarterly Journal of Economics 105(2); 501-526.

[6] Barro R, 1991. Economic Growth in a Cross Section of Countries. Quarterly Journal of Economics 106(2); 407-443.

[7] Bruns B, Mingat A, Rakatomalala R, 2003. A Chance for Every Child: Achieving Universal Primary Education by 2015. Washington, DC: World Bank.

[8] Case A, Lubotsky D, Paxson C, 2002. Economic Status and Health in Childhood: The Origins of the Gradient. The American Economic Review 92(5); 1308-1334.

[9] Case A, Paxson C, 2008. Stature and Status: Height, Ability, and Labor Market Outcomes. Journal of Political Economy 116(3); 499-532.

[10] Cohen D, Soto M, 2007. Growth and Human Capital: Good Data, Good Results. Journal of Economic Growth 12; 51-76.

[11] Das J, Dercon S, Habyarimana J, Krishnana P, 2007. Teacher Shocks and Student Learning: Evidence from Zambia. Journal of Human Resources 42(4); 820-62.

[12] Duflo E, Hanna R, Ryan S, 2008. Monitoring Works: Getting Teachers to Come to School. Mimeo, Massachusetts Institute of Technology.

[13] Eneh OC, 2011. Nigeria's vision 20:2020 - Issues, Challenges and Implications for Development Management. Asian Journal of Rural Development 1; 21-40.

[14] Gorki, P, 2001. Multicultural Education and the Digital Divide. Accessed 5 June, 2004. http://www.edchange.org/multicultural/papers/edchange divide.html.

[15] Griffin K, McKinley T, 1992. Towards a Human Development Strategy. Occasional Paper 6, December.

[16] Hanushek E, Woessmann L, 2009. Do Better Schools Lead to More Growth? Cognitive Skills, Economic Outcomes, and Causation. NBER Working Paper No. 14633, National Bureau of Economic Research, Massachusetts.

[17] Harbison FH, 1972. Human Resources as the Wealth of Nations. New York, Oxford University Press. 
[18] Huyer S, Sikoski T, 2003. Overcoming the Digital Divide: Understanding ICTs and Their Potential for the Empowerment of Women. Instraw Research Paper Series, 1. http://www.uni-instraw.org/pdf/oth-sythesis_paper.pdf.

[19] Ikupa JCB, 1997. Causes and Cure of Examination Malpractices. The Business Administrator 1(1); 38-39.

[20] Jensen M, 2001. African internet users top four million. The African internet. A Status Report.

[21] Kombol MA, 2006. An Assessment of the Problem of ICT Use among Nigerian Media Practitioners: Implications for Media Relations Practitioners in Public Relations. Public Relations Journal 3; 11-28.

[22] Moja T, 2000. Nigeria Education Sector Analysis: An Analytical Synthesis of Performance and Main Issues. Document Produced For the World Bank.

[23] National Universities Commission, 2011. List of Nigerian Universities and years founded. Retrieved from the web 10/10/11. http://www.nuc.edu.ng/pages/universities.asp

[24] Olaniyan DA, Okemakinde T, 2008. Human Capital Theory: Implications for Educational Development. European Journal of Scientific Research 24(2); 157-162.

[25] Oluyeba NF, Daramola SO, 1992. Incidences and Detection of Examination Malpractices in Nigerian Public Examinations. Paper presented on behalf of WAEC on Examination Malpractices, University of Benin, Nigeria.

[26] Park A, Hannum E, 2002. Do Teachers Affect Learning in Developing Countries? Evidence from Student-Teacher Data from China. Unpublished manuscript.

[27] Roux A, 1994. Defence, Human Capital and Economic Development in South Africa. African Defence Review, No 19.

[28] Saraki B, 2009. Vision 2020 and the Challenge of Rebranding Nigeria. Lecture delivered at the National Institute for Policy and Strategic Studies, Kuru, $30^{\text {th }}$ June.

[29] Trostel P, Walker L, Woolley P, 2002. Estimates of the Economic Return to Schooling for 28 Countries. Labour Economics 9; 1-16.

[30] UNIDO, 2003. Competing Through Innovation and Learning. Industrial Development Report 2002/2003. http://www.tips.org.za/node/1193

[31] West African Examinations Council, 2004. Statistics of Incidences of Examination Malpractices. Abuja, Nigeria.

[32] Yesufu TM, 2000. The Human Factor in National Development: Nigeria. Ibadan: Spectrum Books.

[33] Paul Bukuluki, International Letters of Social and Humanistic Sciences 5 (2013) 27-44.

[34] Debiprasad Mukherjee, International Letters of Social and Humanistic Sciences 6 (2013) 41-48.

[35] Sele Sylvester Ebisin, International Letters of Social and Humanistic Sciences 2 (2014) $1-9$.

[36] Pawa Tersoo, International Letters of Social and Humanistic Sciences 3 (2014) 26-36. 
[37] Adoga James Ada, International Letters of Social and Humanistic Sciences 3 (2014) 45-52.

[38] Onyike Maggaret Odu, International Letters of Social and Humanistic Sciences 4 (2014) 31-39.

[39] Uloma Charity Oguzor, International Letters of Social and Humanistic Sciences 4 (2014) 97-104.

[40] Okezie A. Ihugba, Alex Odii, A. C. Njoku, International Letters of Social and Humanistic Sciences 5 (2014) 21-34.

[41] Okezie A. Ihugba, Bankoli Bankong, N. C. Ebomuche, International Letters of Social and Humanistic Sciences 5 (2014) 92-113. 